\title{
The Effect of Financial Constraints and Institutional Ownership on Tax Agressiveness
}

\author{
Ana Fitriana ${ }^{1}$ Nurul Aisyah Rachmawati ${ }^{2}$ \\ ${ }^{1}$ Universitas Trilogi Jakarta, Indonesia 1 \\ 2 Universitas Trilogi Jakarta, Indonesia 2 \\ nurulaisyah@universitas-trilogi.co.id
}

\begin{tabular}{ll}
\hline INFO ARTIKEL & ABSTRAK/ABSTRACT \\
\hline Histori Artikel : & Tax aggressiveness is an action taken by companies in \\
Tgl. Masuk : 14-09-2020 & reducing taxable income through tax planning, either legally \\
Tgl. Diterima : 02-03-2021 & done by tax avoidance or illegally by tax evasion. This \\
Tersedia Online : 31-03-2021 & research examined the effect of financial constraints and \\
\hline Keywords: & institutional ownership on tax aggressiveness. The \\
Financial Constraint, Institutional & population in this research were manufacturing companies \\
Ownership, Tax Agressiveness & listed on the Indonesia Stock Exchange for the period 2016- \\
& 2018. The sampling method used in this research is \\
& purposive sampling and took 56 companies. The analytical \\
& tool used is classic assumption test, multiple linear \\
& regression test, model test and hypothesis test. The results \\
& of this research indicated that (1) financial constraints has a \\
positive effect on tax aggressiveness, (2) institutional & ownership has a positive effect on tax aggressiveness, (3) \\
& institutional ownership weakens the relationship between \\
& financial constraints and tax aggressiveness.
\end{tabular}

\section{PENDAHULUAN}

Pajak merupakan salah satu sumber pendapatan bagi negara. Berdasarkan Undang-Undang (UU) No 28 Tahun 2007 mengenai Ketentuan Umum dan Tata Cara Perpajakan, "Pajak adalah kontribusi wajib kepada negara yang terutang oleh orang pribadi atau badan yang bersifat memaksa berdasarkan Undang-Undang dengan tidak mendapat timbal balik secara langsung dan digunakan untuk keperluan negara bagi sebesar-besarnya kemakmuran rakyat". Menurut Darmawan dan Sukartha (2014), pemungutan pajak tidak selalu mendapat respon yang baik dari wajib pajak. Terutama perusahaan sebagai wajib pajak badan yang berusaha membayar pajak serendah mungkin untuk memaksimalkan keuntungannya. Hal ini berbanding terbalik dengan pemerintah yang menginginkan penerimaan pajak setinggi mungkin guna membiayai kegiatan pemerintah untuk kesejahteraan masyarakat (Welly, 2017). Pajak yang agresif merupakan suatu upaya perusahaan untuk merekayasa laba kena pajak perusahaan dengan cara perencanaan pajak, baik dengan cara yang legal (tax avoidance) maupun dengan cara ilegal (tax evasion) (Frank et al., 2009), penelitian yang dilakukan oleh Mustika (2017) dalam Fitria (2018) juga mengatakan bahwa agresivitas pajak merupakan suatu keinginan perusahaan untuk meminimalisir jumlah beban pajak yang harus dibayar baik dengan cara legal (tax avoidance) maupun secara ilegal (tax evasion) dengan memanfaatkan celahcelah yang terdapat dalam peraturan perpajakan. Pajak penghasilan dari wajib pajak badan memberikan kontribusi besar dalam penerimaan pajak negara. Untuk memperoleh laba yang maksimal, perusahaan akan berusaha mengelola beban pajaknya seminimum mungkin. 
Upaya meminimalkan pembayaran pajak dapat dilakukan secara legal (tax avoidance) maupun secara ilegal (tax evasion).

Salah satu faktor yang diprediksi dapat memengaruhi perusahaan untuk melakukan tindakan agresivitas pajak adalah kendala keuangan (financial constraint). Menurut Koh dan Lee (2015), kendala keuangan yang dialami oleh perusahaan pada umumnya memiliki pendanaan internal yang terbatas. Berdasarkan hasil penelitian yang dilakukan oleh Edwards, Schwab, \& Shevlin (2013), kendala keuangan memberikan pengaruh positif signifikan terhadap perilaku penghindaran pajak. Perusahaan yang mengalami kendala keuangan cenderung untuk melakukan agresivitas pajak karena tingkat kas yang dimiliki oleh perusahaan lebih rendah dibandingkan dengan beban pajak yang harus ditanggung. Hal tersebut dapat disimpulkan bahwa perusahaan yang mengalami kendala keuangan akan memanfaatkan kondisi tersebut untuk kepentingan pelaporan pajak.

Namun, dengan adanya pengawasan dan monitoring dari tata kelola perusahaan (corporate governance) dapat menekan tindakan praktik agresivitas pajak tersebut. Tata kelola perusahaan adalah sistem dan struktur yang mengatur hubungan antara pihak manajemen dengan pemilik, baik yang memiliki saham mayoritas maupun saham minoritas disuatu perusahaan. Penelitian ini, memproksikan tata kelola perusahaan dengan kepemilikan institusional. Menurut Dewi dan Jati (2014), kepemilikan institusional merupakan kepemilikan saham yang dimiliki oleh pemerintah, perusahaan asuransi, investor luar negeri, bank atau institusi lainnya. Upaya penghindaran pajak seharusnya tidak dilakukan oleh manajemen perusahaan karena kepemilikan institusional memiliki peranan penting dalam memantau, mendisiplinkan dan memengaruhi manajer (Maharani dan Suardana, 2014). Semakin tingginya tingkat kepemilikan institusional, maka semakin besar tingkat pengawasan pada manajer. Sehingga, dapat mengurangi konflik kepentingan antara manajemen dan pemegang saham. Oleh karena itu, masalah keagenan dan peluang terjadinya penghindaran pajak dapat berkurang.

Peneliti sebelumnya memproksikan kendala keuangan dengan Wu dan Whited index (Firmansyah dan Bayuaji, 2019; Edwards, Schwab, dan Shevlin, 2013; Tao dan Chen, 2015). Berbeda dengan penelitian sebelumnya, penelitian ini mengadopsi ukuran yang dikembangkan oleh Rachmawati, et al., (2019), yaitu dengan menggabungkan beberapa ukuran kendala keuangan yang sering digunakan dalam penelitian sebelumnya, yaitu rasio utang bersih, rasio cakupan bunga, dan rasio pembayaran deviden. Menurut Rachmawati, et al., (2019) langkah-langkah ini dikombinasikan menggunakan analisis faktor konfirmatori, sehingga bobot masing-masing ukuran lebih tepat, sesuai dengan kontribusinya dalam mengukur kendala keuangan perusahaan. Penelitian ini juga menambahkan variabel kepemilikan institusional sebagai variabel independen untuk mengetahui apakah kepemilikan institusional berpengaruh negatif terhadap agresivitas pajak. Selain itu, dalam penelitian ini kepemilikan institusional juga digunakan sebagai variabel moderasi. Berbeda dengan penelitian sebelumnya yang dilakukan oleh Fadillah (2019), kepemilikan institusional digunakan untuk memoderasi pengaruh nilai perusahaan terhadap penghindaran pajak, dalam penelitian Aprianto dan Dwimulyani (2019), kepemilikan institusional digunakan untuk memoderasi pengaruh variabel leverage terhadap penghindaran pajak. Dalam penelitian ini variabel kepemilikan institusional digunakan untuk memoderasi pengaruh kendala keuangan terhadap agresivitas pajak, tujuan nya adalah untuk mengetahui apakah kepemilikan institusional dapat memperlemah atau memperkuat pengaruh antara kendala keuangan dan agresivitas pajak.

Penelitian ini menggunakan perusahaan manufaktur sebagai sampel karena memiliki berbagai sub sektor industri, serta tidak termasuk dalam jenis perusahaan yang diatur khusus dalam 
peraturan perpajakan, seperti industri property, real estate, konstruksi, pertambangan, agrikultur dan keuangan. Sehingga, perusahaan lebih rentan dalam melakukan agresivitas pelaporan keuangan dan agresivitas pajak dari pada perusahaan yang termasuk kedalam industri yang diatur khusus dalam perpajakan.

Berdasarkan latar belakang tersebut, maka rumusan masalah penelitian ini adalah sebagai berikut: 1) apakah kendala keuangan berpengaruh positif terhadap agresivitas pajak?, 2) apakah kepemilikan institusional berpengaruh negatif terhadap agresivitas pajak?, 3) apakah kepemilikan institusional memperlemah pengaruh positif kendala keuangan terhadap agresivitas pajak?.

Adapun tujuan dari penelitian ini adalah: 1) Menganalisis apakah kendala keuangan berpengaruh positif terhadap agresivitas pajak. 2) Menganalisis apakah kepemilikan institusional berpengaruh negatif terhadap agresivitas pajak. 3) Menganalisis apakah kepemilikan institusional memperlemah pengaruh positif kendala keuangan terhadap agresivitas pajak.

Manfaat dari penelitian ini secara teori adalah dapat dijadikan sebagai salah satu literatur untuk melakukan penelitian berikutnya. Secara praktis manfaat dari penelitian ini adalah: 1) bagi perusahaan, diharapkan dapat memberikan informasi yang dapat digunakan sebagai tumpuan dalam membuat kebijakan manajemen dan perusahaan dapat mempertimbangkan pengawasan dari kepemilikan institusional sebelum melakukan tindakan agresivitas pajak terutama pada perusahaan yang mengalami kendala keuangan, 2) bagi regulator, diharapkan dapat memberikan informasi kepada pihak regulator agar dapat meningkatkan pengawasan dan monitoring terhadap perusahaan yang memiliki kendala keuangan, karena perusahaan yang mengalami kendala keuangan lebih cenderung untuk melakukan agresivitas pajak. 3) bagi investor, dapat memberikan informasi tentang agresivitas pajak, sehingga diharapkan dapat menjadi bahan pertimbangan bagi investor dalam membuat keputusan investasi yang tepat.

Secara garis besar, penelitian ini terdiri dari pendahuluan, kerangka teoritis dan pengembangan hipotesis, metodologi penelitian, hasi dan pembahasan, kesimpulan, serta implikasi dan keterbatasan.

\section{KERANGKA TEORITIS DAN PENGEMBANGAN HIPOTESIS}

\section{Pajak}

Menurut Undang-Undang No 28 tahun 2007 tentang Ketentuan umum dan tata cara perpajakan. Pajak adalah kontribusi wajib kepada negara yang terutang oleh orang pribadi atau badan yang bersifat memaksa berdasarkan Undang-Undang, dengan tidak medapat timbal balik secara langsung dan digunakan untuk keperluan negara bagi sebesar-besarnya kemakmuran rakyat. Sementara, menurut Prof. Dr. Rochmat Soemitro, SH dalam Mardiasmo (2016), pajak adalah iuran rakyat kepada kas negara berdasarkan Undang-Undang (yang dapat dipaksakan) dengan tidak mendapat jasa timbal (kontraprestasi) yang langsung dapat ditunjukkan dan digunakan untuk membayar pengeluaran umum.

\section{Teori Keagenan (Agency Teory)}

Teori keagenan merupakan suatu perjanjian kontrak antara manajemen perusahaan (agent) dan pemilik perusahaan (principal). Para manajer diberi wewenang dalam membuat keputusan oleh pemilik perusahaan. Hal ini menciptakan potensi konflik kepentingan atau dikenal dengan teori keagenan. Menurut Hendriyani dan Tahar (2015), principal cenderung berusaha untuk memaksimalkan laba (risk takers), sedangkan agent sebagai pelaksana aktivitas cenderung tidak menyukai risiko yang terlalu besar (risk adverse). Ketika principal dan agent memiliki kepentingan untuk memaksimalkan kepentingannya masing-masing, maka terdapat kemungkinan bahwa agent bertindak tidak untuk kepentingan principal. Hanum (2013) dalam Mulyani, Wijayanti, dan 
Masitoh (2018), menjelaskan pemikiran mengenai corporate governance didasari oleh teori keagenan di mana dalam melakukan pengelolaan perusahaan harus diawasi dan dikendalikan untuk memastikan bahwa pengelolaan dilakukan dengan penuh kepatuhan terhadap peraturan dan ketentuan yang berlaku.

\section{Corporate Governance}

Menurut Peraturan Menteri Negara BUMN, Nomor PER/01/MB4/2011 tentang good corporate governance secara definisi merupakan sistem yang mengatur serta mengendalikan perusahaan agar tercipta nilai tambah bagi semua stackholder. Menurut Rizqiasih (2010), esensi dari corporate governance adalah peningkatan kinerja perusahaan melalui pengawasan atau pemantauan kinerja manajemen dan adanya akuntabilitas manajemen terhadap stakeholders dan pemangku kepentingan lainnya, berdasarkan kerangka aturan dan peraturan yang berlaku.

Berdasarkan beberapa pengertian mengenai corporate governance yang telah diuraikan, dapat ditarik kesimpulan bahwa corporate governance atau tata kelola perusahaan merupakan sistem dan struktur yang mengatur hubungan antara pihak manajemen dengan pemegang saham untuk mengendalikan perusahaan melalui pengawasan dan pemantauan kinerja manajemen.

\section{Agresivitas Pajak}

Menurut Frank et al., (2009), agresivitas pajak merupakan tindakan yang dilakukan oleh perusahaan dalam mengurangi pendapatan kena pajak melalui perencanaan pajak (tax planning), baik secara legal yang dilakukan dengan penghindaran pajak (tax avoidance) maupun secara ilegal yang dilakukan dengan penggelapan pajak (tax evasion). Lanis dan Richardson (2013) mengatakan bahwa definisi agresivitas pajak adalah semua upaya yang dilakukan oleh manajemen untuk menurunkan jumlah beban pajak dari yang seharusnya dibayar oleh perusahaan. Slemord (2004) menjelaskan bahwa agresivitas pajak merupakan kegiatan yang spesifik mengarah kepada transaksi yang tujuan utamanya adalah untuk menurunkan kewajiban pajak perusahaan (Nugroho dan Firmansyah, 2017). Dengan demikian, dapat ditarik suatu kesimpulan bahwa agresivitas pajak merupakan suatu tindakan yang dilakukan oleh perusahaan untuk mengurangi jumlah beban pajak yang seharusnya dibayar oleh perusahaan yang dilakukan baik secara legal maupun ilegal.

\section{Kendala Keuangan}

Platt dan Platt (2002) dalam Hermawan dan Riandoko (2018), berpendapat bahwa kendala keuangan merupakan suatu kondisi dimana keuangan perusahaan menurun sebelum mengalami kebangkrutan atau likuidasi. Menurut Koh dan Lee (2015), perusahaan yang mengalami kendala keuangan umumnya memiliki pendanaan internal yang terbatas. Chen dan Lai (2012), menjelaskan bahwa sumber pendanaan internal perusahaan yang mengalami kendala keuangan dapat dilakukan memalui praktik agresivitas pajak. Dengan terlibat dalam praktik penghindaran pajak yang agresif, perusahaan akan menghemat kas untuk membantu menyelesaikan masalah kekurangan investasi yang dialami oleh perusahaan yang mengalami kendala keuangan (Firmansyah dan Bayuaji, 2019).

\section{Kepemilikan Institusional}

Menurut Tarjo (2008), kepemilikan institusinal merupakan kepemilikan saham yang dimiliki oleh institusi atau lembaga seperti pemerintahan, perusahaan asuransi, bank, perusahaan investasi dan kepemilikan institusi lainnya (Nugroho dan Firmansyah, 2017).Menurut Faisal (2004), kepemilikan institusional merupakan pihak yang mengawasi perusahaan yang memiliki jumlah kepemilikan institusi di atas $5 \%$, kepemilikan institusi tersebut mampu memonitor manajemen lebih besar. Institusi yang dimaksud dapat berupa pemerintah, yayasan, bank, perusahaan asuransi, perusahaan investasi, dana pensiun, perusahaan berbentuk perseroan (PT), dan institusi lainnya (Ngadiman dan Puspitasari, 2014). 


\section{Pengaruh Kendala Keuangan terhadap Agresivitas Pajak}

Perusahaan yang mengalami kendala keuangan umumnya memiliki pendanaan internal yang terbatas (Koh dan Lee, 2015). Edwards, Schwab, dan Shevlin (2013), juga menjelaskan bahwa tax planning atau perencanaan pajak dapat dijadikan sebagai sumber pembiayaan alternatif. Karena sumber pembiayaan seperti utang atau ekuitas menjadi lebih sulit diperoleh ketika perusahaan mengalami kendala keuangan. Oleh karena itu, perusahaan yang mengalami kendala keuangan cenderung menyimpan dana melalui praktik penghindaran pajak untuk mempertahankan daya saing perusahaan dan mengurangi masalah kurangnya investasi (Tao dan Chen, 2015).

Badertscher, et al., (2009) dalam Koh dan Lee (2015) menyatakan bahwa perusahaan akan cenderung tidak melakukan agresivitas pajak apabila perusahaan tersebut memiliki arus kas bebas yang relatif tinggi, karena mereka memiliki kemampuan untuk membayar pajak. Sedangkan perusahaan yang memiliki arus kas terbatas umumnya mengalami kendala keuangan. Sehingga, lebih cenderung untuk melakukan tindakan agresivitas pajak. Penelitian yang dilakukan oleh Rachmawati, et al., (2019)'; Firmansyah dan Bayuaji (2019); dan Tao dan Chen (2015), menunjukan bahwa kendala keuangan berpengaruh positif terhadap agresivitas pajak. Berdasarkan penelitian terdahulu, maka hipotesis dalam penelitian ini adalah sebagai berikut.

$\mathrm{H}_{1}$ : Kendala keuangan berpengaruh positif terhadap agresivitas pajak perusahaan.

\section{Pengaruh Kepemilikan institusional terhadap Agresivitas Pajak}

\footnotetext{
Menurut Desai dan Dharmapala (2009) kepemilikan institusional merupakan salah satu tolak ukur dalam corporate governance untuk menengahi tindakan penghindaran pajak yang dapat memengaruhi nilai perusahaan. Dengan adanya pengendalian dan tingkat
}

pengawasan yang tinggi dari kepemilikan institusional akan memberikan aspek positif pada penghindaran pajak (Fadli, Ratnawati, dan Kurnia, 2016). Dalam penelitian Amelia, Pratomo, dan Kurnia (2017), juga mengatakan bahwa dengan adanya kepemilikan institusional pada suatu perusahaan akan mendorong peningkatan pengawasan yang lebih optimal terhadap kinerja manajemen. Jadi semakin tinggi tingkat kepemilikan institusional, maka akan semakin besar tingkat pengawasan kepada manajerial sehingga konflik kepentingan manajemen dapat dikurangi. Hasil penelitian ini sejalan dengan penelitian yang dilakukan oleh Nugroho dan Firmansyah (2017) yang menyimpulkan bahwa dengan adanya peningkatan kepemilikan institusional akan mengurangi kepemilikan yang dimiliki oleh manajemen dan seharusnya meningkatkan pengawasan terhadap manajemen perusahaan. Dengan adanya pengawasan yang lebih dari institusi lain, manajemen akan lebih berhati-hati dalam mengambil keputusan yang membahayakan pemegang saham seperti keputusan untuk meningkatkan agresivitas pajak. Putranti dan Setiawanta (2015) dan Feranika (2016,) juga menunjukan hasil yang sama, bahwa kepemilikan institusional akan menekan usaha perusahaan untuk mengurangi beban pajak. Berdasarkan penelitian terdahulu, maka hipotesis dalam penelitian ini adalah sebagai berikut.

H2: Kepemilikan institusional berpengaruh negatif terhadap agresivitas pajak perusahaan.

\section{Kepemilikan Institusional memoderasi pengaruh Kendala Keuangan terhadap Agresivitas Pajak}

Kepemilikan institusional merupakan bagian yang tidak terpisahkan dari corporate governance. Corporate governance adalah seperangkat peraturan yang mengatur antara pemegang saham, pengurus (pengelola) perusahaan, pihak kreditur, pemerintah, karyawan, serta para pemegang kepentingan internal dan eksternal (Ningsapiti dan Hidayat, 2010). Menurut Rizqiasih (2010), esensi dari 
corporate governance adalah peningkatan kinerja perusahaan melalui pengawasan atau pemantauan kinerja manajemen dan adanya akuntabilitas manajemen terhadap stakeholders dan pemangku kepentingan lainnya, berdasarkan kerangka aturan dan peraturan yang berlaku.

Berdasarkan literatur sebelumnya, kendala keuangan merupakan suatu kondisi dimana perusahaan memiliki pendanaan internal yang terbatas (Koh dan Lee, 2015). Perusahaan yang mengalami kendala keuangan cenderung untuk melakukan agresivitas pajak karena tingkat kas yang dimiliki oleh perusahaan lebih rendah dibandingkan dengan beban pajak yang harus ditanggung. Dengan demikian penelitian ini menggunakan variabel kepemilikan institusional sebagai variabel moderasi karena kepemilikan institusional memiliki peran pengawasan, sehingga diharapkan dapat meminimalisir tindakan agresivitas pajak yang dilakukan oleh perusahaan yang mengalami kendala keuangan. dengan demikian, hipotesis yang dirumuskan pada penelitian ini adalah sebagai berikut.

H3: Kepemilikan institusional memperlemah pengaruh positif antara kendala keuangan dan agresivitas pajak

\section{METODOLOGI PENELITIAN}

Populasi yang digunakan dalam penelitian ini adalah seluruh perusahaan manufaktur yang terdaftar di Bursa Efek Indonesia (BEI) periode 2016-2018, yaitu tiga tahun terakhir dari masa penelitian. Hal tersebut juga didasarkan pada rasio pajak selama 3 tahun terakhir masih berada di bawah 15 persen. Pada tahun 2018 hanya mencapai 11,5 persen meskipun naik cukup signifikan dari tahun sebelumnya yang hanya sebesar 10,7 persen dan di Tahun 2016 total SPT yang dilaporkan WP badan hanya meningkat 1 persen dari tahun sebelumnya, yakni dari 543.092 ribu menjadi 549.059 ribu SPT (Siregar, 2019). Dalam penelitian ini sampel yang diambil menggunakan teknik purposive sampling dengan kriteria: 1) Perusahaan manufaktur yang terdaftar di Bursa Efek Indonesia (BEI) selama periode 2016-2018; 2) Perusahaan tersebut telah mempublikasikan laporan keuangan tahunan selama periode tahun 2016-2018 yang berisi data informasi yang lengkap dan laporan keuangan tersebut telah diaudit yang disertai dengan laporan auditor independen; 3) Perusahaan tidak sedang mengalami kerugian selama periode 2016-2018; karena pada saat rugi perusahaan tidak membayar pajak; 4) Menghilangkan atau membuang data outlier.

Berdasarkan kriteria di atas diperoleh sampel sebanyak 56 perusahaan setiap tahunnya. Sehingga jumlah sampel secara keseluruhan untuk periode 32016 2018 adalah sebanyak 168 perusahaan.

Sumber data yang digunakan dalam penelitian ini adalah data sekunder yang diperoleh dari website Bursa Efek Indonesia, studi literatur dan pustaka yang berkaitan dengan masalah penelitian, dan penelitian-penelitian terdahulu.

Teknik pengumpulan data yang digunakan dalam penelitian ini adalah teknik dokumen berupa laporan keuangan yang diperoleh dari Bursa Efek Indonesia melalui website www.idx.co.id.

\section{Analisis Data}

Metode analisis yang digunakan dalam penelitian ini adalah analisis regresi berganda (multiple regression), yang dinyatakan dalam persamaan berikut: Model hipotesis $\mathrm{H}_{1}$, dan $\mathrm{H}_{2}$ :

$$
\begin{aligned}
& \mathrm{NPM}_{i t}=\alpha_{0}+\alpha_{1} \mathrm{FC}_{\mathrm{it}}+\alpha_{2} \mathrm{KI}_{\mathrm{it}}+\alpha_{3} \mathrm{SIZE}_{\mathrm{it}}+ \\
& \alpha_{4} \mathrm{LEV}_{\mathrm{it}}+\alpha_{5} \mathrm{GROWTH}_{\mathrm{it}}+\mathrm{e}
\end{aligned}
$$

Model Hiptesis $\mathrm{H}_{3}$ :

$$
\begin{aligned}
& N M_{i t}=\beta_{0}+\beta_{1} F_{i t}+\beta_{2} K_{i t}+\beta_{3} F_{i t}{ }^{*} K_{i t} \\
& +\beta_{4} \text { SIZE }_{i t}+\beta_{5} L V_{i t}+\beta_{6} G R O W T H_{i t}+e
\end{aligned}
$$

\begin{tabular}{|c|c|}
\hline $\mathrm{NPM}_{\text {it }}$ & $\begin{array}{l}\text { :Agresivitas pajak } \\
\text { perusahaan i pada tahun } t\end{array}$ \\
\hline $\mathrm{FC}_{\text {it }}$ & $\begin{array}{l}\text { :Kendala keuangan } \\
\text { perusahaan i pada tahun } \mathrm{t}\end{array}$ \\
\hline $\mathrm{Kl}_{\text {it }}$ & $\begin{array}{l}\text { :Kepemilikan institusional } \\
\text { perusahaan i pada tahun } \mathrm{t}\end{array}$ \\
\hline SIZE & $\begin{array}{l}\text { :Ukuran perusahaan } \\
\text { perusahaan i pada tahun } \mathrm{t}\end{array}$ \\
\hline
\end{tabular}

Keterangan: 


$\begin{array}{ll}\text { LEV }_{\text {it }} & \begin{array}{l}\text { :Leverage perusahaan } \\ \text { pada tahun } \mathrm{i}\end{array} \\ \text { GROWTH }_{\text {it }} & \begin{array}{l}\text { :Pertumbuhan penjualan } \\ \text { perusahaan i pada tahun } \mathrm{t}\end{array} \\ \mathrm{e}: & \begin{array}{l}\text { error }\end{array}\end{array}$

\section{Definisi Operasionalisasi Variabel dan Pengukurannya}

Menurut (Frank at al, 2009), agresivitas pajak merupakan tindakan yang dilakukan untuk menurunkan laba sehingga pajak yang dibayarkan rendah, baik dengan cara yang sesuai atau tidak sesuai dengan peraturan perpajakan yang berlaku. Mengadopsi penelitian sebelumnya yang dilakukan oleh Adisamartha dan Noviari (2015) dan (Ni Kadek \& I Wayan, 2017) penelitian ini diproksikan dengan Net Profit Margin (NPM) index yang diperoleh dari NPM perusahaan dibagi dengan NPM Industri. Apabila NPM perusahaan berada di bawah NPM industri, terdapat indikasi bahwa perusahaan tersebut tidak melaporkan laba yang sebenarnya. Karena, perusahaan dapat memanipulasi laporan keuangannya sedemikian rupa dengan berbagai tujuan, salah satunya adalah untuk penghindaran pajak (Adisamartha dan Noviari, 2015).

\section{$N P M I=$ Net Profit Margin Perusahaan}

Net Profit Margin Industri

\section{Kendala Keuangan (FC)}

Mengikuti penelitian sebelumnya yang dilakukan oleh Rachmawati, et al., (2019) studi ini menggabungkan tiga ukuran kendala keuangan menggunakan analisis faktor konfirmatori untuk menghasilkan variabel kendala keuangan baru (FC). Karena, dengan menggunakan model analisis faktor konfirmatori, dapat mengevaluasi validitas konstruk secara tepat. Sehingga, ukuran baru dari kendala keuangan lebih komprehensif dan mampu menyederhanakan interpretasi hasil.

Tiga ukuran kendala keuangan tersebut di antaranya: (1) Rasio Utang Bersih (Net Debt Ratio), Rachmawati, et al., (2019) berpendapat bahwa tingginya rasio utang bersih yang dimiliki perusahaan cenderung akan menghadapi kendala keuangan karena perusahaan tersebut memiliki keterbatasan pendanaan internal. Rasio Utang Bersih atau Net Debt Ratio diukur dengan total utang dibagi dengan total aktiva. (2) Rasio Cakupan Bunga (Interest Coverage Ratio) Kendala keuangan akan lebih memungkinkan dihadapi oleh perusahaan yang memiliki rasio cakupan bunga yang rendah dibandingkan dengan perusahaan yang memiliki rasio cakupan bunga tinggi. Mengikuti Claessens, et al., 2006 dan Rachmawati, et al., 2019, rasio cakupan bunga diukur dengan laba sebelum bunga dan pajak dibagi dengan biaya bunga. Karena hubungan antara rasio cakupan bunga dan kendala keuangan negatif, maka dikali dengan (-1) untuk memfasilitasi interpretasi hasil. (3) Rasio Pembayaran Deviden (Dividen Payout Ratio), Menurut Claessenset et al., (2006), perusahaan yang dapat membayar dividen berarti kurang memiliki kendala keuangan dibandingkan dengan perusahaan yang tidak membayar dividen (Rachmawati, et al., 2019). Rasio pembayaran dividen adalah dividend per share dibagi dengan earning per share, kemudian dikali dengan (-1) untuk memfasilitasi interpretasi hasil, karena hubungan antara rasio pembayaran deviden dan kendala keuangan negatif.

\section{Kepemilikan Institusional (KI)}

Kepemilikan institusional merupakan kepemilikan saham yang dimiliki oleh pemerintah, investor luar negeri, perusahaan asuransi, perseroan terbatas, maupun bank yang memiliki peranan lebih besar dalam pengawasan terhadap manajemen perusahaan.

Kepemilikan institusional $=$ Jumlah lembar saham yang dimiliki institusional

Total saham yang beredar

\section{Ukuran Perusahaan (SIZE)}

Menurut Widjadja (2009),Ukuran perusahaan merupakan ukuran besar kecilnya perusahaan dilihat dari besarnya 
nilai pasar saham, nilai penjulan atau nilai aktiva (Hadi dan Mangoting, 2014). Semakin besar perusahaan tersebut maka akan semakin banyak aset yang dimiliki sehingga biaya penyusutan menjadi besar dan perusahaan membayar pajak dengan jumlah kecil. Artinya, semakin besar ukuran perusahaan semakin agresif dalam praktik penghindaran pajak. Hal tersebut sesuai dengan peneltian yang telah dilakukan oleh Hadi dan Mangoting (2014); Ngadiman dan Puspitasari (2014); dan Jaya, Zirman, dan Ilham (2018). Ukuran perusahaan dalam penelitian ini diproksikan dengan total aset.

$$
S I Z E=\operatorname{Ln}(\text { Total Assets) }
$$

\section{Leverage (LEV)}

Menurut Ngadiman dan Puspitasari (2014), leverage adalah penggunaan dana yang berasal dari pihak eksternal berupa hutang untuk membiayai investasi dan perusahaan. Pembiayaan melalui hutang terutama hutang jangka panjang akan menimbulkan beban bunga yang dapat mengurangi beban pajak yang harus dibayar oleh perusahaan. semakin tinggi nilai leverage maka perusahaan semakin agresif terhadap penghindaran pajak. Hal ini sejalan dengan penelitian yang dilakukan oleh Ariawan dan Setiawan (2017); Zahirah, Nurazlina dan Rusli (2017); Fitria (2018); Fadli, Ratnawati, dan Kurnia (2016). Leverage dalam penelitian ini diukur dengan rasio total kewajiban (Fadli, Ratnawati, dan Kurnia, 2016).

$$
\text { Leverage }=\frac{\text { Total Kewajiban }}{\text { Total Aset }}
$$

\section{Growth (Pertumbuhan Penjualan)}

Menurut Budiman dan Setiyono (2012), sales growth atau pertumbuhan penjualan dapat menunjukan perkembangan tingkat penjualan dari tahun ke tahun. Oleh karena itu perkembangan tersebut bisa meningkat atau menurun (Ridho, 2016). Jika pertumbuhan penjualan meningkat maka profit akan meningkat, sehingga pajak yang harus dibayarkan perusahaan lebih besar. Dengan demikian, hal tersebut dapat mendorong perusahaan untuk melakukan praktik agresivitas pajak (Aprianto dan Dwimulyani, 2019). Hal ini sejalan dengan penelitian yang dilakukan oleh Oktamawati (2017). Pertumbuhan penjualan dilambangkan dengan GROWTH dan dihitung dengan menggunakan rumus sebagai berikut:

Pertumbuhan Penjualan $=$

Total Penjualan $\mathrm{t}-$ Total Penjualan $\mathrm{t}-1$

Total Penjualan t-1

\section{HASIL DAN PEMBAHASAN}

\section{Analisis Statistik Deskriptif}

Analisis statistik deskriptif dilakukan untuk melihat nilai rata-rata (mean), nilai standar devasi, nilai median, nilai miimum dan maksimum dari masing-masing variabel penelitian. Pada tabel 1.

Tabel 1

Deskripsi Variabel Penelitian Tahun 2016-2018

\begin{tabular}{|c|c|c|c|c|c|c|}
\hline Var & N & Mean & Median & $\begin{array}{c}\text { Std. } \\
\text { Dev }\end{array}$ & Min & Max \\
\hline $\begin{array}{c}\text { NPM } \\
\text { index }\end{array}$ & 168 & 2,196 & 1,356 & 2,582 & $-0,109$ & 11,137 \\
\hline FC & 168 & $-0,000$ & 0,166 & 0,999 & $-5,328$ & 2,935 \\
\hline KI & 168 & 0,794 & 0,888 & 0,213 & 0,051 & 0,999 \\
\hline LEV & 168 & 0,512 & 0,413 & 0,496 & 0,001 & 3,734 \\
\hline SIZE & 168 & 19,397 & 19,230 & 1,661 & 15,7 & 22,892 \\
\hline GROWTH & 168 & 0,129 & 0,092 & 0,203 & $-0,5$ & 0,993 \\
\hline
\end{tabular}

Sumber: Data Olahan, 2020

\section{Analisis Korelasi}

Berikut ini adalah hasil dari uji Pairwise Correlation yang terdapat pada Tabel 2. Tabel ini menjelaskan hubungan korelasi variabel independen dengan variabel dependen. Berdasarkan hasil pengujian pada tabel tersebut tidak 
terdapat masalah multikolinearitas karena tidak terdapat koefisien korelasi antar variabel yang melebihi 0.8 .

Tabel 2

Hasil Pengujian

Pearson Correlation

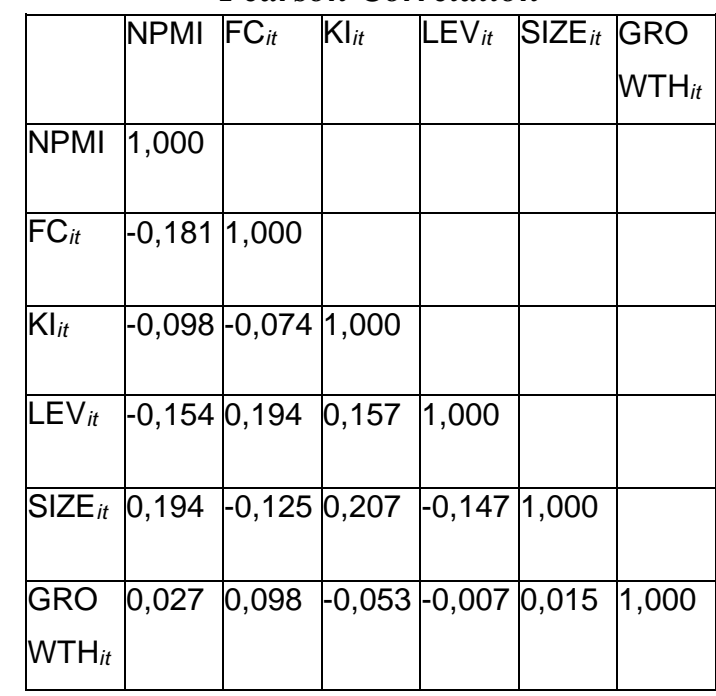

Sumber: Data Olahan, 2020

\section{Uji Multikolinearitas}

Berdasarkan hasil uji VIF pada model agresivitas pajak baik dengan moderasi maupun tanpa moderasi, menunjukan tidak terdapat masalah multikolinearitas. Karena tidak terdapat variabel yang memiliki nilai tolerance kurang dari 0,1 .

\section{Uji Hteroskedastisitas}

Berdasarkan hasil uji BreuschPagan/Cook-Weisberg pada model agresivitas pajak baik dengan moderasi maupun tanpa moderasi, menunjukan adanya masalah heteroskedastisitas karena nilai Prob $>$ chi2 berada di bawah 0,05. Dengan demikian, dilakukan treatment robust untuk menghilangkan masalah heteroskedastisitas tersebut.

\section{Hasil Analisis Data}

Hasil dari analisis regresi data panel pada tabel 2 bertujuan untuk mengetahui pengaruh dari kendala keuangan dan kepemilikan institusional terhadap agresivitas pajak serta untuk menentukan persamaan regresi.

\section{Tabel 3}

\section{Hasil Regresi Model Agresivitas Pajak setelah dilakukan Treatment Robust}

\begin{tabular}{|c|c|c|c|c|}
\hline Var & $\begin{array}{l}\text { Prediksi } \\
\text { Tanda }\end{array}$ & Coef & $\mathrm{T}$ & $P>[t]$ \\
\hline$\overline{\mathrm{FC}_{\text {it }}}$ & $+(\mathrm{H} 1)$ & $-0,436$ & $-3,74$ & $0,0315^{\star \star}$ \\
\hline $\mathrm{Kl}_{i t}$ & $-(\mathrm{H} 2)$ & $-1,878$ & $-3,6$ & $0,0365^{\star \star}$ \\
\hline $\mathrm{LEV}_{\text {it }}$ & & $-0,004$ & $-3,69$ & $0,000^{* \star *}$ \\
\hline SIZE & & 0,307 & 2,26 & $0,025^{\star *}$ \\
\hline GROWTH $_{i t}$ & & 0,416 & 0,51 & 0,609 \\
\hline cons & & $-2,307$ & $-0,93$ & 0,355 \\
\hline \multicolumn{3}{|l|}{ R-Square } & \multicolumn{2}{|c|}{0,088} \\
\hline \multicolumn{3}{|c|}{ Adjusted R-square } & \multicolumn{2}{|c|}{0,060} \\
\hline \multicolumn{3}{|c|}{ Prob (F-Statistic) } & \multicolumn{2}{|c|}{0,000} \\
\hline
\end{tabular}

Sumber: Data Olahan, 2020

Berdasarkan tabel 3 hasil pengujian pada variabel kendala keuangan menunjukan nilai signifikansi 0,0315 lebih kecil dari tingkat signifikansi yaitu 5\% dengan nilai koefisien -0,436. Variabel kendala keuangan memiliki hubungan yang terbalik dengan variabel agresivitas pajak. Nilai koefisien negatif menunjukkan bahwa semakin tinggi nilai kendala keuangan suatu perusahaan maka nilai NPM index akan semakin rendah. Nilai NPM index yang rendah mengindikasikan bahwa NPM perusahaan lebih kecil dari NPM industri. Artinya, terdapat indikasi bahwa perusahaan tersebut tidak melaporkan laba yang sebenarnya karena sedang berada di bawah NPM industri. Sehingga semakin tinggi nilai kendala keuangan suatu perusahaan, semakin cenderung untuk melakukan agresivitas pajak. Dengan demikian, kendala keuangan berpengaruh positif terhadap agresivitas pajak. Hal ini membuktikan bahwa sumber pendanaan internal perusahaan dalam kendala keuangan dapat dilakukan melalui praktik agresivitas 
pajak. Seingga hipotesis yang telah dirumuskan pada $\mathrm{H} 1$ diterima. Penelitian ini sejalan dengan penelitian yang telah dilakukan oleh Rachmawati et al.,(2019); Firmansyah dan Bayuaji (2019); Edwards, Schwab, dan Shevlin (2013); Tao dan Chen (2015). Penelitian ini juga menunjukan bahwa ukuran kendala keuangan yang dikembangkan oleh Rachmawati et al.,(2019), lebih baik dalam menjelaskan tingkat agresivitas pajak. Karena lebih komprehensif dan lebih sederhana dalam menginterpretasikan hasil penelitian.

Hasil pada tabel 3 menunjukan bahwa pada variabel kepemilikan institusional nilai signifikansi 0,036 lebih kecil dari tingkat signifikansi yaitu $5 \%$ dengan nilai koefisien -1,878. Nilai koefisien negatif menunjukan bahwa, semakin tinggi nilai kepemilikan institusional maka nilai NPM index semakin rendah. Nilai NPM yang rendah menunjukkan bahwa perusahaan semakin cenderung dalam melakukan praktik penghindaran pajak. Oleh karena itu, adanya kepemilikan institusional tidak mampu menekan perusahaan dalam melakukan praktik penghindaran pajak. Artinya, kepemilikan institusional berpengaruh positif terhadap agresivitas pajak. Sehingga hipotesis yang telah dirumuskan pada $\mathrm{H} 2$ ditolak.

Penelitian ini membuktikan bahwa kepemilikan institusional tidak bisa melakukan pengawasan secara langsung terhadap praktik penghindaran pajak agresif yang dilakukan oleh perusahaan. Persentase kepemilikan saham yang dimiliki institusional pada penelitian ini mayoritas dimiliki oleh perusahaan biasa atau perseroan terbatas. Sehingga, fungsi monitoring yang dimiliki oleh institusional kurang kuat dalam meminimalisir atau menekan tindakan penghindaran pajak. Penelitian ini sejalan dengan penelitian yang telah dilakukan oleh Putri dan Lawita (2019); Dewi N. M (2019); Ariawan dan Setiawan (2017), yang menunjukan bahwa kpemilikan institusional berpengaruh positif terhadap agresivitas pajak.

\begin{tabular}{|c|c|c|c|c|}
\hline \multicolumn{5}{|c|}{$\begin{array}{c}\text { Hasil Regresi Model Agresivitas } \\
\text { Pajak dengan Moderasi Kepemilikan } \\
\text { Institusional setelah dilakukan } \\
\text { Treatmen Robust }\end{array}$} \\
\hline Variabel & $\begin{array}{c}\text { Prediksi } \\
\text { Tanda }\end{array}$ & Coef & $\mathrm{T}$ & $P>[t]$ \\
\hline $\mathrm{FC}_{\text {it }}$ & & $-0,556$ & -2.56 & $0,011^{* *}$ \\
\hline $\mathrm{Kl}_{\text {it }}$ & & $-1,939$ & $-2,02$ & $0,045^{\star *}$ \\
\hline $\mathrm{FC}_{i t}{ }^{*} \mathrm{KI}_{i t}$ & $-(\mathrm{H} 3)$ & $\mid 1,777$ & 3,46 & $0,043^{\star \star}$ \\
\hline LEV $_{\text {it }}$ & & $-0,323$ & $-0,79$ & 0,429 \\
\hline $\mathrm{SIZE}_{i t}$ & & 0,334 & 2,73 & $0,007^{*}$ \\
\hline GROWTH $_{i t}$ & & 0,466 & 0,49 & 0,625 \\
\hline _cons & & $-4,165$ & $-1,71$ & 0,089 \\
\hline \multicolumn{5}{|c|}{${ }^{* *}$ signifikansi pada alpha $5 \%$} \\
\hline \multicolumn{5}{|c|}{${ }^{\star \star *}$ signifikansi pada alpha $1 \%$} \\
\hline \multicolumn{3}{|l|}{ R-squared } & \multicolumn{2}{|c|}{0,107} \\
\hline \multicolumn{3}{|c|}{ Adjusted R-squared } & \multicolumn{2}{|c|}{0,074} \\
\hline \multicolumn{3}{|c|}{ Prob (F-Statistic) } & \multicolumn{2}{|c|}{0,004} \\
\hline
\end{tabular}

Sumber: Data Olahan, 2020

Berdasarkan hasil pada tabel 4 variabel kepemilikan institusional memoderasi hubungan kendala keuangan dengan agresivitas pajak, menunjukkan nilai signifikansi sebesar 0,043 dengan nilai koefisien sebesar 1,776. Nilai koefisien yang positif menunjukkan bahwa semakin tinggi nilai kepemilikan institusional maka semakin tinggi juga nilai NPM Index, nilai NPM index yang tinggi menunjukkan bahwa perusahan semakin tidak agresif terhadap penghindaran pajak. Artinya, kepemilikan institusional dapat menekan tindakan agresivitas pajak pada perusahaan yang mengalami kendala keuangan. Sehingga hipotesis yang telah dirumuskan pada $\mathrm{H} 3$ diterima. Peran yang dimiliki oleh kepemilikan institusional

\section{Tabel 4}


dalam memantau, mendisiplinkan dan memengaruhi manajer mendorong munculnya pengawasan yang lebih optimal terhadap kinerja manajer terutama pada perusahaan yang mengalami kendala keuangan. Karena perusahaan yang mengalami kendala keuangan cenderung lebih agresif dalam praktik penghindaran pajak. Sehingga, dengan adanya pengawasan yang lebih dari institusi lain, manajer akan lebih berhatihati dalam mengambil keputusan yang membahayakan bagi pemegang saham seperti keputusan untuk meningkatkan agresivitas pajak.

Variabel leverage menunjukan nilai koefisien -0,323 dengan nilai probabilitas sebesar 0,429 . hasil yang ditunjukan pada tabel 4 mengindikasikan bahwa variabel leverage tidak memiliki pengaruh terhadap agresivitas pajak. Artinya perusahaan dengan tingkat leverage yang tinggi justru akan meningkatkan laba periode berjalan. Sehingga, perusahaan cenderung untuk tidak melakukan agresivitas pajak. Penelitian ini sejalan dengan penelitian Savitri dan Rahmawati (2017); Andhari dan Sukartha (2017); Adisamartha dan Noviari (2015) yang menyatakan bahwa leverage tidak berpengaruh terhadap agresivitas pajak.

Variabel size atau ukuran perusahaan menunjukan nilai koefisien 0,334 dengan nilai probabilitas sebesar 0,007 . hasil yang ditunjukan pada tabel 4 mengindikasikan bahwa variabel size berpengaruh signifikan terhadap agresivitas pajak dengan level signifikansi $5 \%$. Artinya, semakin tinggi ukuran suatu perusahaan maka cenderung lebih agresif dalam melakukan praktik penghindaran pajak. Penelitian ini sejalan dengan penelitian yang dilakukan oleh Latifah (2018); Andeswari (2018); dan Jaya, Zirman, dan llham (2018) yang menyatakan bahwa ukuran perusahaan (size) berpengaruh terhadap agresivitas pajak.

Variabel growth atau pertumbuhan penjualan menunjukan nilai koefisien 0,466 dengan nilai probabilitas sebesar 0,625 . hasil yang ditunjukan pada Tabel 4 mengindikasikan bahwa variabel growth tidak berpengaruh terhadap agresivitas pajak. Penelitian ini sejalan dengan penelitian Ridho (2016); Aprianto dan Dwimulyani (2019) yang menyatakan bahwa pertumbuhan penjualan tidak berpengaruh terhadap tindakan agresivitas pajak. Artinya besar kecilnya pertumbuhan penjualan tidak dapat memengaruhi keputusan perusahaan untuk melakukan agresivitas pajak.

\section{KESIMPULAN}

Kendala keuangan berpengaruh positif dengan agresivitas pajak. Semakin tinggi nilai kendala keuangan suatu perusahaan maka akan menurunkan nilai NPM index. NPM index yang rendah mengindikasikan bahwa perusahaan semakin cenderung untuk melakukan tindakan agresivitas pajak. Hasil penelitian ini mendukung penelitian Rachmawati et al.,(2019); Firmansyah dan Bayuaji (2019); Edwards, Schwab, dan Shevlin (2013).

kepemilikan institusional berpengaruh positif terhadap agresivitas pajak. Semakin tinggi nilai kepemilikan institusional maka perusahaan semakin cenderung dalam melakukan praktik penghindaran pajak. Sehingga, fungsi monitoring yang dimiliki oleh kepemilikan institusional tidak dapat berepengaruh secara langsung terhadap praktik penghindaran pajak agresif yang dilakukan oleh perusahaan. Hasil penelitian ini mendukung penelitian dari Putri dan Lawita (2019); Dewi N. M (2019); Ariawan dan Setiawan (2017).

Kepemilikan institusional dapat memperlemah hubungan antara kendala keuangan dengan agresivitas pajak. Artinya, peran monitoring yang dimiliki oleh kepemilikan institusional dapat berpengaruh pada perusahaan yang mengalami kendala keuangan. Dengan demikian, kepemilikan institusional dapat menekan praktik penghindaran pajak yang agresif pada perusahaan yang mengalami kendala keuangan.

\section{IMPLIKASI DAN KETERBATASAN}

\section{Implikasi}


Bagi perusahaan yang mengalami kendala keuangan diharapkan dapat mempertimbangkan pengawasan dan monitoring dari kepemilikan institusional sebelum melakukan agresivitas pajak. Bagi regulator diharapkan dapat meningkatkan pengawasan terhadap perusahaan yang mengalami kendala keuangan. Karena perusahaan yang mengalami kendala keuangan cenderung lebih agresif dalam melakukan praktik penghindaran pajak. Bagi peneliti selanjutnya diharapkan lebih memperluas objek penelitian hingga seluruh perusahaan yang terdaftar di Bursa Efek Indonesia dan memperpanjang periode penelitian sehingga hasil penelitian yang diperoleh lebih komprehensif. Bagi Investor diharapkan dapat berhati-hati dalam berinvestasi pada perusahaan yang mengalami kendala keuangan dan apabila sudah terlanjur berinvestasi pada perusahaan yang mengalami kendala keuangan, maka investor harus melakukan pengawasan secara ketat agar perusahaan tersebut tidak melakukan praktik penghindaran pajak.

\section{Keterbatasan}

Adapun keterbatasan dalam
penelitian ini adalah sampel yang
digunakan pada penelitian ini adalah
perusahaan manufaktur yang terdaftar di
Bursa Efek Indonesia, sehingga hasil
penelitian ini tidak dapat digeneralisasi
untuk sektor industri lainnya. Periode
pengamatan yang digunakan dalam
penelitian ini adalah tahun 2017-2019.
Sehingga data penelitian tidak dapat
mewakili keseluruhan data yang ada di
Bursa Efek Indonesia. Pada variabel
kepemilikan institusional persentase
kepemilikan saham mayoritas dimiliki oleh
perusahaan biasa atau perseroan terbatas
(PT), sehingga fungsi pengawasan tidak
kuat dan hasil menjadi bias.

\section{Saran}

Berdasarkan

penelitian yang telah diuraikan sebelumnya, terdapat saran-saran untuk peneliti selanjutnya, diantaranya: Peneliti selanjutnya dapat menambahkan industri lain untuk dijadikan sampel penelitian, sehingga hasilnya dapat digeneralisasi. Menambahkan perode waktu pengamatan agar hasil yang diperoleh lebih berkualitas. Pada variabel kepemilikan institusional disarankan hanya menggunakan persentase kepemilikan saham yang dimiliki oleh perusahaan keuangan saja, agar fungsi pengawasan yang dimiliki lebih kuat.

\section{REFERENCES}

Adisamartha, I. P., \& Noviari, N. (2015, Desember). Pengaruh Likuiditas, Leverage, Intensitas Persediaan, dan Intensitas Aset Tetap pada Tingkat Agresivitas Wajib Pajak Badan. E-Jurnal Akuntansi Universitas Udayana, 13(3), 9731000.

Amelia, V. M., Pratomo, D., \& Kurnia. (2017, Agustus). Pengaruh Kepemilikan Institusional dan Kepemilikan Manajerial dengan Variabel Kontrol Ukuran Perusahaan dan Leverage terhadap Penghindaran Pajak. eProceeding of management, 4(2), 1510.

Andeswari, D. A. (2018). Pengaruh Profitabilitas, Capital Intensity Ratio, Leverage, Pertumbuhan Penjualan, Ukuran Perusahaan, Koneksi Politik dan Good Corporate Governance terhadap Tax Avoidance. In Skripsi. Yogyakarta: Universitas Islam Indonesia.

Andhari, P. A., \& Sukartha, I. M. (2017, Maret). Pengaruh Pengungkapan Corporate Social Responsibility, Profitabilitas, Inventory Intensity, Capital Intensity dan Leverage pada Agresivitas Pajak. E-Journal Akuntansi Universitas Udayana, 18(3), 2115-2142.

Aprianto, M., \& Dwimulyani, S. (2019). Pengaruh Sales Growth dan Leverage terhadap Tax 
Avoidance dengan Kepemilikan Institusional sebagai Variabel Moderasi. Prosiding Seminar Nasional Pakar ke 2, 2.

Ariawan, I. A., \& Setiawan, P. E. (2017, Maret). Pengaruh Dewan Komisaris Independen, Kepemilikan Institusional, Profitabilitas dan Leverage terhadap Tax Avoidance. E-Jurnal Akuntansi Universitas Udayana, 18(3), 1831-1859.

Dermawan, I. H., \& Sukartha, I. (2014). Pengaruh Penerapan Corporate Governance, Leverage, Return on Assets dan Ukuran Perusahaan pada Penghindaran Pajak. EJurnal Akuntansi Universitas Udayana, 9(1), 143-161.

Dewi, N. K., \& Jati, I. K. (2014). Pengaruh Karakter Eksekutif, Karakteristik Perusahaan, dan Dimensi Tata Kelola Perusahaan yang Baik pada Tax Avoidance di Bursa Efek Indonesia. Jurnal Universitas Udayana .

Dewi, N. M. (2019). Pengaruh Kepemilikan Institusional, Dewan Komisaris Independen dan Komite Audit terhadap Penghindaran Pajak pada Perusahaan Perbankan yang terdaftar di Bursa Efek Indonesia Periode 2012-2016. Maksimum Media Akuntansi Universitas Muhammdiyah Semarang, 9(2), 171-189.

Edwards, A., Schwab, C., \& Shevlin, T. (2013). Financial Constraint and The Incentive for Tax Planning. American Taxation Association Midyear Meeting.

Fadillah, H. (2018, Juni). Pengaruh Tax Avoidance terhadap Nilai Perusahaan dengan Kepemilikan Institusional sebagai Vriabel Moderasi. Journal IImiah Akuntansi
Fakultas Ekonomi, 4(1), 117133.

Fadli, I., Ratnawati, V., \& Kurnia, P. (2016, Februari). Pengaruh Likuiditas, Leverage, Komisaris Independen, Manajemen Laba, dan Kepemilikan Institusional terhadap Agresivitas Pajak Perusahaan. JOM Fekon, 3(1).

Firmansyah, A., \& Bayuaji, R. (2019, October). Financial Constraint, Invesment Opportunity Set, Financial Reporting Aggressiveness, Tax Aggresiveness: Evidence From Indonesia Manufacturing Companies. Academy of Accounting and Financial Studied Journal, 23(5).

Fitria, E. F. (2018, Mei). Pengaruh Capital Intensity, Inventory Intensity, Profitabilitas dan Leverage terhadap Agresivitas Pajak. Ejournal STIE Dewantara, 2(1).

Frank, M., L, L., \& S, R. (2009). Tax Reporting Aggressiveness and its Relation to Aggressive Financial Reporting. Accounting Review, 84(2), 467-96. Retrieved from www.aaapubs.org

Hadi, J., \& Mangoting, Y. (2014). Pengaruh Struktur Kepemilikan dan Karakteristik Dewan terhadap Agresivitas Pajak. Tax and Accounting Review, 4(2).

Hermawan, J. P., \& Riandoko, R. (2018, April). Do Firm Facing Increases in Financial Constraint Tend to Generate Cash through Tax Avoidance? Empirical Evidence from Indonesia Publicly Listed Firms. Working Paper. Retrieved from https://www.researchgate.net/pub lication/329084849 
Jaya, F., Zirman, \& Ilham, E. (2018, Januari-Juni). Pengaruh Likuiditas, Profitabilitas, Ukuran perusahaan, Capital Intencity dan Pengungkapan Corporate Social Responsibility terhadap Agresivitas pajak. JOM Feb, 1(1).

Koh, Y., \& Lee, H.-A. (2015, July). The Effect of Financial Factors on Firms' Financial and Tax Reporting Decisions. Asian Review of Accounting, 23(2), 110138. Retrieved from Https://www.researchgate.net/pub lication/281388923

Lanis, R., \& Richardson, G. (2013). Corporate Social Responsibility and Tax Aggressiveness: a test of legitimacy theory. Accounting, Auditing and Accountability Journal, 26(1), 75-100.

Latifah, U. N. (2018). Pengaruh Corporate Governance, Capital Intensity dan Inventory Intensity terhadap Agresivitas Pajak. In Skripsi. Surakarta: Institut Agama Islam Negeri Surakarta .

Maharani, I. A., \& Suardana, K. A. (2014). Pengaruh Corporate Governance, Profitabilitas, dan Karakter Eksekutif pada Tax Avoidance Perusahaan Manufaktur. E-Jurnal Akuntansi Universitas Udayana, 9(2), 525-539.

Mardiasmo. (2016). Perpajakan. Bandung: Andi.

Mulyani, S., Wijayanti, A., \& Masitoh, E. (2018). Pengaruh Corporate Governance terhadap Tax Avoidance. Jurnal Riset Akuntansi dan Bisnis Airlangga, 3(1), 322340. Retrieved from www.jraba.org

Ngadiman, \& Puspitasari, C. (2014, September). Pengaruh Leverage, Kepemilikan Institusional, dan Ukuran Perusahaan terhadap
Penghindaran Pajak (Tax Avoidance). Jurnal Akuntansi, 18(3), 408-421.

Ni Kadek , K. Y., \& I Wayan, R. (2017, Oktober). Pengaruh Likuiditas dan Corporate Social Responsibility pada Agresivitas pajak dengan Corporate Governance sebagai Variabel Pemoderasi. E-Jurnal Akuntansi Universitas Udayana, 21(1), 730-759.

Nugroho, A. S., \& Firmansyah, A. (2017, September). Pengaruh Financial Distress, Real Earnings Management dan Corporate Governance terhadap Tax Aggressiveness. Journal of Business Administration, 1(2), 163-182.

Oktamawati, M. (2017, Maret). Pengaruh Karakter Eksekutif, Komite Audit, Ukuran Perusahaan, Leverage, Pertumbuhan Penjualan, dan Profitbilitas terhadap Tax Avoidance. Jurnal Akuntansi Bisnis, 15(1).

Putri, A. A., \& Lawita, N. F. (2019, Juni). Pengaruh Kepemilikan Institusional dan Kepemilikan Manajerial terhadap Penghindaran Pajak. Jurnal Akuntansi dan Ekonomika, 9(1).

Rachmawati, N. A., Utama, S., Martani, D., \& Wardhani, R. (2019). Determinants of the complementary level of financial and tax aggresiveness: a crosscountry study. Int. J. Managerial and Financial Accounting, 11(2), 145-166.

Republik Indonesia. (2011). Peraturan Menteri Negara BUMN PER/01/MB4/2011, tentang Penerapan Tata Kelola Perusahaan.

Ridho, M. (2016). Pengaruh Ukuran Perusahaan, Leverage, 
Profitabilitas dan Sales Growth terhadap Penghindaran Pajak pada Perusahaan Manufaktur di Bursa Efek Indonesia tahun 20102014. In Skripsi. Jakarta: Universitas Islam Negeri Syarif Hidayatullah .

Ririn, H., \& Tahar, A. (2015, Maret). Analisis Faktor-faktor yang Mempengaruhi Tingkat Pengungkapan Laporan Keuangan Pemerintah Provinsi di Indonesia. Jurnal Bisnis dan Ekonomi, 22(1), 25-33.

Rizqiasih, P. D., \& Prabowo, T. W. (2010). Pengaruh Struktur Governance terhadap Fee Audit/Eksternal. Doctoral dissertation Universitas Diponegoro.

Savitri, D. A., \& Rahmawati, I. N. (2017, November). Pengaruh Leverage, Intensitas Persediaan, Intensitas Aset Tetap, dan Profitabilitas terhadap Agresivitas Pajak. Jurnal IImu Manajemen dan Akuntansi Terapan (JIMAT), 8(2).

Tao, C., \& Chen, L. (2015). Does Information Asymmetry Affect Corporate Tax Aggressiveness? International Conference on AsiaPacific Financial Markets (CAFM).

Undang-Undang Republik Indonesia No 28 Tahun 2007. (n.d.). In Ketentuan Umum dan Tata Cara Perpajakan.

Zahirah, A., Nurazlina, \& Rusli. (2017, April). Pengaruh Leverage, Kepemilikan Institusional, Kepemilikan Manajerial, dan Ukuran Perusahaan terhadap Penghindaran Pajak. JOM Fekon, 4(1), 3548. 